\title{
O Mundo da Criança Sendo-Com Câncer em Tratamento Oncológico Revelado por Meio do Brinquedo Terapêutico Dramático
}

\author{
Fonseca, Marileise Roberta Antoneli; Melo, Luciana de Lione \\ Universidade Estadual de Campinas — roberta_antoneli@yahoo.com.br
}

No Brasil, o câncer tem se destacado como um problema de saúde pública e, como a segunda causa de morte em crianças e adolescentes entre um e 19 anos. o câncer infantil é uma doença crônica que demanda um tratamento longo, desgastante, invasivo e doloroso e implica alterações nos hábitos de vida da criança e da família. É importante que a criança com câncer tenha uma boa qualidade de vida, diminuindo possíveis sequelas por meio de ações específicas que visem o bem-estar e proporcionem relações sociais e afetivas. o brinquedo terapêutico é uma brincadeira estruturada que possibilita à criança vivenciar situações geradoras de estresse, ao mesmo tempo em que visa alcançar domínio sobre essas situações. o brinquedo terapêutico dramático permite à criança exteriorizar seus sentimentos, revivendo eventos desagradáveis. Objetivo: compreender a criança pré-escolar em tratamento oncológico por meio do brinquedo terapêutico dramático. Método: estudo qualitativo fundamentado na fenomenologia - análise da estrutura do fenômeno situado, realizado numa casa de apoio à criança com câncer, no município de Campinas/SP. o projeto foi aprovado pelo Comitê de Ética em Pesquisa, no 58949/12. Participaram cinco crianças, com idade entre três e seis anos, que estavam em tratamento oncológico e que residiam provisoriamente na casa de apoio, no período de janeiro a maio de 2013. As crianças foram convidadas, a participarem de sessões de brinquedo terapêutico dramático que se iniciou com a seguinte questão norteadora: "Vamos brincar de uma criança que está com câncer?" Os discursos das crianças, durante o brincar, foram gravados, transcritos na íntegra e analisados a partir do referencial da análise da estrutura do fenômeno situado, emergindo quatro categorias temáticas. Mergulhando no mundo da doença e do tratamento expressa o comportamento da criança e sua interação com os diversos procedimentos realizados em busca da cura da doença. Experienciando a doença por meio da percepção do funcionamento do corpo evidencia a compreensão da criança sobre o funcionamento do corpo diante da doença e do tratamento. Vivenciando os procedimentos terapêuticos é o momento onde a criança dramatiza situações hospitalares, demonstrando grande satisfação ao enfrentar seus medos. Sendo-criança é o emergir do próprio eu, que continua existindo, ainda que em tratamento oncológico. Conclusão: as sessões de brinquedo terapêutico dramático possibilitaram às crianças a continuidade do desenvolvimento infantil, promovendo descontração, alegria e relaxamento, pois a doença e o tratamento afetaram significativamente o comportamento das crianças. Recomenda-se a utilização de estratégias que facilitem o relacionamento entre a criança e o profissional de saúde e promova a compreensão do processo de adoecimento, como o brinquedo terapêutico.

Fonseca, Marileise Roberta Antoneli; Melo, Luciana de Lione. O Mundo da Criança Sendo-Com Câncer em Tratamento Oncológico Revelado por Meio do Brinquedo Terapêutico Dramático. In: Anais do Congresso Internacional de Humanidades \& Humanização em Saúde [= Blucher Medical Proceedings, num.2, vol.1]. São Paulo: Editora Blucher, 2014. ISSN 2357-7282

DOI 10.5151/medpro-cihhs-10213 